\title{
7 \\ Risk Analysis Integrating Livelihood and Economic Impacts of Wastewater Irrigation on Health
}

\author{
Marites M. Tiongco, Clare A. Narrod and Kelly Bidwell
}

\begin{abstract}
This chapter provides a brief review of methods and approaches for evaluating the consequences of using wastewater to irrigate vegetables. The following five objectives are considered: (a) analysing poor producers' and consumers' knowledge, attitudes and perceptions of the risks associated with pathogen contamination/ exposure, and the economic consequences on health and livelihoods; (b) analysing the costs and benefits of non-treatment interventions at the farm level (e.g. drip irrigation and cessation of irrigation prior to harvest) and post-harvest level (e.g. washing and disinfection of vegetables after harvesting); (c) identifying costeffective interventions for reducing the risk of waterborne disease associated with wastewater use for irrigation; (d) estimating producers' and consumers' willingness to pay for or adopt non-treatment interventions at multiple stages along the food chain; and (e) evaluating the long-term economic and livelihood impacts of adopting those non-treatment interventions that are identified as cost-effective and targeted at poor producers and consumers. The chapter concludes by synthesizing a methodological framework for the collection and analysis of data to assess the livelihood and economic impacts of illness caused by microbial pathogens from wastewater.
\end{abstract}




\section{INTRODUCTION}

It is estimated that up to 20 million hectares of agricultural land in developing countries are being irrigated with raw or diluted wastewater (see Chapter 1 and Jiménez and Asano, 2004; Scott et al., 2004). Ensink et al. (2004) stated that the use of wastewater for irrigating agricultural crops, including high-value crops such as fruits and vegetables is practised in many parts of the world because of the scarcity of clean water resources and because wastewater is seen by small-scale producers as a cheap means to improve soil fertility and add essential nutrients for their crops. Although wastewater has a high nutrient value, it also has a food-safety risk due to the possibility of the transmission of pathogens (including bacteria, viruses, and protozoa) on fruits and vegetables posing a potential human health hazard.

Direct consumption of food cultivated on land irrigated with wastewater and ingestion of soil resulting from improper hygiene that transfers soil from hands to mouth (not washing soiled hands before eating) are examples of exposure pathways to pathogenic micro-organisms from organic manure, fertilizers, pesticides and effluents causing infectious diseases including typhoid fever, rotavirus infection, cholera and hepatitis A (IWMI, 2006; Scott et al., 2004). In addition, farmers and irrigation workers can acquire helminth infections and parasitic diseases due to direct contact with untreated wastewater and contaminated soils, especially if exposed for a long duration (Ensink, 2006). Despite this knowledge, it is often difficult to get farmers, particularly poor small-scale producers, to alter behaviour by applying risk-reducing practices to wastewater irrigation, because food production using wastewater generates significant livelihood ${ }^{1}$ opportunities (Buechler and Devi 2005a, 2005b; Hamilton et al., 2005; Toze, 2006). Therefore, effective risk reduction strategies must account for farmers' practices and attitudes towards the adoption of intervention to mitigate these risks.

The chapter evaluates methods to assess the cost-effectiveness of such interventions and suggests that overcoming this challenge must address four interrelated issues. First, small-scale producers using wastewater are often not well informed of the potential health risks of infection and disease both to themselves and to consumers of wastewater-irrigated produce. Second, small-scale producers primarily act on knowledge of the positive, short-term economic effects on livelihood security even though they may understand the negative, long-term health implications. Third, interventions to reduce the food-safety risk associated with using wastewater for irrigation in urban and peri-urban areas tend to be largescale and not cost-effective for the poor to implement. In the case of consumers, their behavioural choices may be influenced by past behaviour and experiences, and their perception of relative risk. For example, if consumers have been eating raw vegetables for years and have not become ill, they may view themselves as not being at risk, or that the probability of contamination is very low, and so they could be 
reluctant to make long-term changes in their food preparation and consumption practices. Finally, decision-makers do not have sufficient information as to whether producers and consumers would be willing to pay for or adopt interventions to reduce health risks if cost-effective measures were available.

To better understand the complexity of these issues and find possible solutions to minimize risk of infection and illness from consuming and producing vegetables irrigated with wastewater, a risk analysis can be carried out. Risk analysis is an internationally recognized framework used for identifying and assessing disease and food-safety risks, for evaluating risk-management options and for assessing publichealth and food-safety challenges (see Box 7.1). It involves a risk assessment in terms of both biological and economic impacts, an evaluation of risk-management choices and a risk-communication strategy so as to identify a portfolio of costeffective control measures to reduce a specified risk. Although there have been a number of risk assessments on the use of wastewater on food crops (Asano et al., 1992; Fattal et al., 2004; van Ginneken and Oron, 2000; Hamilton et al., 2006; Petterson et al., 2001; Shuval et al., 1997; Tanaka et al., 1998), to the authors' knowledge there are no risk analyses that incorporate adoption of interventions into the framework, with the exception of the theoretical approach presented by Malcolm et al. (2004) and Chapters 13 and 16 of this book. Understanding awareness, knowledge and perceptions towards risk, as well as assessing people's willingness to pay for or adopt those cost-effective risk-reducing strategies are important determinants in making choices as to which measure to adopt. Further, although risk management has a monitoring and review component, it does not monitor and evaluate the long-term impact of adopting a mitigation strategy on livelihood outcomes. As there are many poor and small-scale producers involved in food production in developing countries who use wastewater, there is a need to understand the economic impact of food-safety hazards on their livelihood outcomes (income, health and nutrition and gender equality) and on stakeholders' willingness to adopt cost-effective risk-reducing strategies.

In this chapter, we propose the use of a modified risk analysis framework that takes into account people's willingness to pay for or adopt cost-effective ways to reduce health risks associated with wastewater use and to improve livelihoods. We explore how the risk analysis framework and the methodologies for evaluating the costs and benefits, and cost-effectiveness of risk-reducing options, can be integrated with methodologies for assessing perceptions, knowledge and attitudes about risk, and willingness to pay for or adopt control measures. An attempt is made to identify appropriate methodologies for evaluating the long-term impacts of adopting cost-effective non-treatment interventions targeted at producers and consumers, specifically how these affect productivity and livelihood outcomes. 


\section{BOX 7.1 RISK ANALYSIS FRAMEWORK}

Risk analysis is a useful tool for decision-making that 'maps' an action or event on to measurable endpoints. Risk analysis typically consists of three essential components that are integrated with each other: risk assessment, risk management and risk communication (see Figure 7.1). In the case of foodborne diseases, the risk assessment involves the evaluation of the likelihood of a foodborne hazard as well as the biological and economic consequences of that hazard. In other words, it helps to understand what can go wrong, how disease introduction or spread can happen, how likely microbiological risks arising from wastewater use for irrigation can be characterized and the consequences. Risk management involves evaluation of how best to mitigate the risk and to determine, using cost-benefit and cost-effective analyses, the cost to society of the action. Risk communication involves identifying ways to interact with the public as stakeholders and informing them of risk-assessment findings such as cost-effective risk-reduction measures and decision tools to aid decision-makers. Additionally, it supports decision-makers in making adequately informed decisions, evaluating policy alternatives and establishing food-safety control measures.

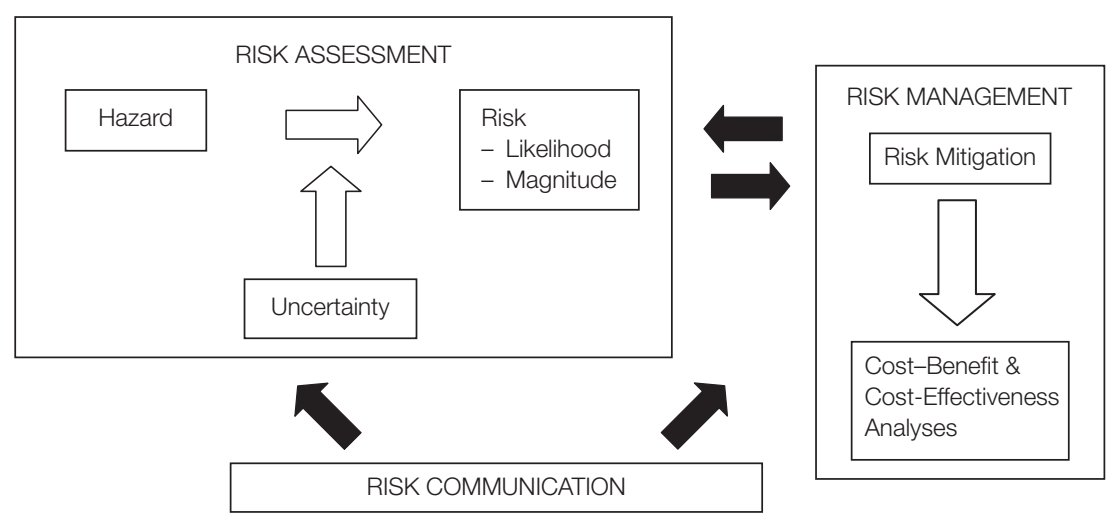

Figure 7.1 Risk analysis framework

\section{ECONOMIC METHODS FOR EVALUATING IMPACT OF DISEASE AND INTERVENTIONS TO REDUCE RISK}

The effects of wastewater use on health and its social and economic consequences for farmers, agricultural labourers and their household members, and consumers of wastewater-irrigated produce, have been studied in some areas but these studies lack the evaluation of economic consequences on livelihood outcomes such as income, wealth and food and nutrition security (Blumenthal et al., 2000; Ensink et al., 2003; Feenstra et al., 2000; van der Hoek et al., 2002; Shuval et al., 1986). 
In the case of health risks, it is necessary to take a farm to fork perspective for microbial risks because pathogens can enter virtually anywhere along the food chain. Health impacts can arise through farmers' or others' contact with irrigation water, or through direct or indirect contact of non-contaminated vegetables with contaminated ones, and through unhygienic handling, i.e. soiled hands transmitting pathogens to vegetables. In health economics, disability-adjusted life years (DALYs, see chapters 2 and 3) are used to facilitate the comparison of the economic risks and cost-effectiveness of various forms of interventions. Currently this approach is the best measure available for quantifying health benefits in terms of: reduced diarrhoeal and gastrointestinal infections, and helminth and related intestinal nematode infections; improved irrigation water quality; and reduced cost of illness to consumers (costs of illness include medicines, hospitalization and doctor's consultation) and reduced productivity loss (e.g. forgone earnings). Thus, quantifying the economic impacts of wastewater-based microbial pathogen exposure on health is important in order to provide decision-makers with evidencebased information on the economic efficiency and technological feasibility of the risk reduction strategies at selected points along the food chain.

However, it is difficult to quantify the magnitude of the economic impact of foodborne disease on human health due to exposure to excreta-related pathogens and consumption of pathogen-contaminated crops irrigated with wastewater. Factors such as multiplication of microbial pathogens as the contaminated product moves along the food chain and the reaction of market actors and consumers have to be taken into consideration. For instance, consumers may lose confidence in the safety of the products they consume as a result of a waterborne disease outbreak, which further leads to market-share losses due to decline in demand for fruit and vegetables. Consumer responses usually depend on the existing information they have, their level of awareness and the changes in relative prices when making choices about the products they purchase or consume, particularly if there is a food- safety issue that would affect their well-being. Addressing the impact on consumer confidence in food safety could be a basis for estimating costs and benefits of reducing risk and preventing disease.

\section{Approaches for assessing the costs and benefits of interventions}

There are two widespread economic approaches to valuing changes to health and risk: cost-benefit analysis and cost-effectiveness analysis. Cost-benefit analysis (CBA) is used to understand the efficiency of the intervention relative to the baseline (no intervention) in an objective, quantitative way so as to determine where an intervention should be initiated, continued, or abandoned. The costs of an intervention and benefits of its impact are often evaluated in terms of the public's willingness to pay to acquire (benefits) or the willingness to pay to avoid them (costs); see next section on evaluating willingness to pay. Direct costs can 


\section{BOX 7.2 NON-TREATMENT INTERVENTIONS}

The risk of using untreated wastewater for irrigation can be reduced through nontreatment options or multiple combinations of these options. These include farm-level wastewater management and harvest and post-harvest interventions.

At the farm level, farmers can reduce health risks (such as skin infections, muscular pains, intestinal nematode infections and sore feet) and crop contamination by adopting the following farming practices:

- drip irrigation: uses drip kits and containers for wastewater storage;

- improving methods of water distribution such as the use of flood and furrow irrigation or watering cans to fetch water (primarily to reduce collection of protozoan ova);

- avoiding soil splash when using watering cans (e.g. by lowering the height of application or using water hoses);

- ceasing irrigation before harvesting (one to several days before harvest) to allow natural pathogen die-off;

- avoiding stirring up sediment while fetching water with cans;

- reducing contact with irrigation water.

Not washing harvested crops in irrigation water can reduce pathogen contamination. At the post-harvest stage, which includes handling and transport, market display, storage and preparation in the kitchen, the following can be practised:

- Improving vegetable-washing before serving using vinegar (broad availability but the most expensive option) and disinfectants such as chlorine tablets (available at selected vendors) and potassium permanganate (available in about every third pharmacy in the cities sampled by Keraita, 2008);

- improving food safety and hygiene.

A combination of low-cost non-treatment options from farm to post-harvest comprises the 'multiple-barrier approach' (see Chapters 2 and 12) supported by the new WHO Guidelines where intervention measures are placed along the food chain to achieve aggregate effect in reducing health risks (WHO, 2006).

Source: Keraita (2008); Qadir et al. (2008)

be estimated using any or a combination of the following approaches: economicengineering analysis; cost survey analysis; econometric estimations of costs; and simulation (Fearne et al., 2004; Havelaar et al., 2006; Valeeva et al., 2004).

In the economic-engineering analysis approach, the costs of an intervention are estimated for each individual procedure needed to implement it, and then the total cost is the summation of individual costs. These include the costs of implementing and monitoring risk-mitigation measures as shown in Table 7.1. In addition to these structural costs are incidental costs (productivity losses) and market-revenue losses that are related to detection of contamination or exposure. This approach also allows for efficiency analysis via estimation of cost functions based on available 
Table 7.1 Cost estimates of non-treatment interventions at the farm level ${ }^{a}$

\begin{tabular}{|c|c|c|c|}
\hline $\begin{array}{l}\text { Interventions } \\
\text { (see Keraita, 2008) }\end{array}$ & $\begin{array}{l}\text { Fixed costs } \\
\text { (US\$) }\end{array}$ & $\begin{array}{c}\text { Operation, } \\
\text { maintenance and } \\
\text { labour costs (US\$/yr) }\end{array}$ & $\begin{array}{c}\text { Total cost estimates } \\
\text { year } 1 \text { (US\$) }\end{array}$ \\
\hline \multicolumn{4}{|l|}{ Drip kits ${ }^{c}$} \\
\hline Locally made & 105 & 36 & 141 \\
\hline Imported & 175 & 36 & 211 \\
\hline $\begin{array}{l}\text { Current practice without } \\
\text { intervention }\end{array}$ & 10 & 15 & 25 \\
\hline Improved use of watering cans & 10 & 20 & 30 \\
\hline Cessation before harvest ${ }^{d}$ & $\begin{array}{l}\text { Forgone benefit } \\
\text { (yield loss) }\end{array}$ & & \\
\hline For 2 days & 40 & 14 & 54 \\
\hline For 4 days & 70 & 13 & 83 \\
\hline For 6 days & 100 & 12 & 112 \\
\hline \multicolumn{4}{|l|}{ Pond use for improved } \\
\hline sedimentation & 17 & 25 & 42 \\
\hline $\begin{array}{l}\text { Sand filtration (two rows of } \\
\text { sand bags) }\end{array}$ & 24 & 43 & 67 \\
\hline
\end{tabular}

a Based on a typical farm of ca. 0.03ha (irrigated vegetable farming in urban areas in Ghana)

${ }^{b}$ Cost related to the preparation of the water sources (stream, dugout) not included

${ }^{c}$ Based on the requirement of 1 kit/0.004ha i.e. about 7 kits per farm, incl. water buckets

${ }^{d}$ Losses are estimated as $5 \%$ of total harvest per day. Selling price of lettuce estimated as 1 US $\$ / \mathrm{m}^{2}$

Source: Hope and Keraita (2009)

technical and economic data. The main advantage of the engineering approach is its transparency as it is easy to understand how the numbers were estimated (Fearne et al., 2004).

Benefits can be derived from the value of reduction of economic costs based on the costs associated with implementing each intervention that would likely reduce the risk of illness from microbial pathogens or avoid crop-production losses, or in terms of savings due to reduced costs of illness or changes in the composition of demand (Smith et al., 2007; Bennett et al., 2004; Disney et al., 2003). Indirect benefits result from increases in productivity or costs offset, for example, reduced cost of illness and lives saved due to reduced mortality. An intervention would be considered Pareto optimal if it improves the situation for some people, but does not make anybody worse off. Thus, for governments, acceptable interventions (or policies) are typically those for which expected benefits are greater than or equal to expected costs.

Once the risks from microbial pathogens due to wastewater use have been estimated and described, and the costs and benefits of risk-reduction measures have been calculated, a cost-effectiveness analysis (CEA) can then be conducted to understand the trade-offs of the risk-reduction methods available. To do this, 
information is needed on the economic costs of chronic exposure (which also include infection, illness and death) to the disease, the investments and costs associated with the different risk-reduction options, the probability of effectiveness of the various risk-reduction measures and the probabilities of chronic exposure under different risk-reduction measures.

Simulation can be performed using different sets of scenarios: do nothing or no intervention (baseline); a single intervention; or a combination of interventions.

The difference between the baseline and a single intervention or combination is the gain in health (DALYs averted) or income due to the reduction in disease burden from the interventions. The costs of each intervention are then compared with the gains to identify the most cost-effective intervention (or a combination of interventions) at different levels of resource availability. The comparison of the different interventions against the most cost-effective shows areas of efficiency, while an intervention for higher resource levels shows what should be done if those resources are available.

To illustrate, four hypothetical options (A, B, C, D) to reduce risk are considered. As shown in Figure 7.2, the $\mathrm{x}$-axis is the marginal cost of adding one of the new options compared to the baseline. The $y$-axis is the percentage reduction in risk over the baseline. Option D can be excluded as a choice since option B is superior to option $\mathrm{D}$ in the sense that $\mathrm{B}$ is both more effective and less costly. Choices of adoption strategy can be limited to non-dominated options A, B and $\mathrm{C}$, which could result in maximum possible benefits for a given cost (Glauber and Narrod, 2001; Malcolm et al., 2004). Option C is the optimal risk-mitigation measure, where the marginal benefit of the risk-mitigation policy is equal to the marginal cost.

Results of the CEA are important inputs for risk-management decisions. They help weigh available options for reducing risk of illness due to wastewater use in terms of efficiency, technological feasibility and practicality at selected points along the food chain.

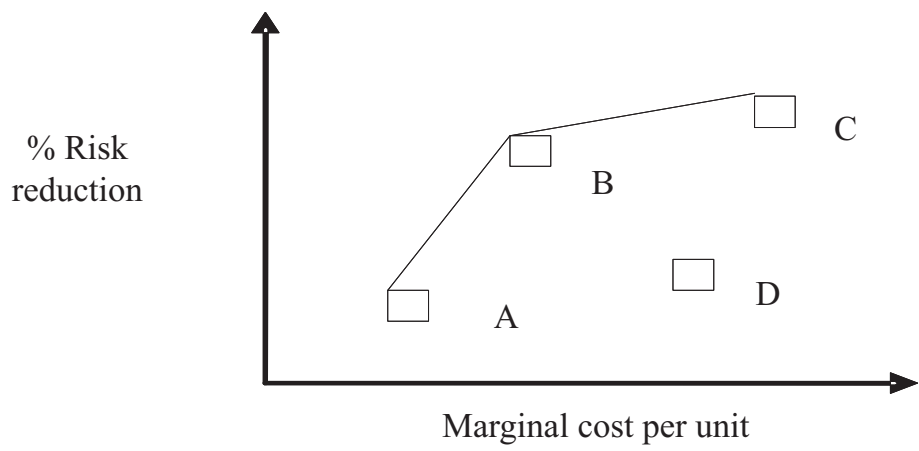

Figure 7.2 Risk reduction/cost trade-off 


\section{Evaluating willingness to pay for an intervention}

The willingness to pay (WTP) for or adopt control strategies and willingness to test technologies or interventions such as those described above can be estimated using stated preference methods such as contingent valuation or conjoint analysis (Hammitt, 2000). Subsequently, the estimated WTP can be compared to the costs of these strategies and technologies to determine those that are the most economically efficient. In the contingent valuation method, consumers will be given a hypothetical scenario involving the choice between different risk levels of food contamination, from no contamination as the base scenario to a high level of contamination (for a thorough review of the application of this method, see Birol et al., 2006; Buzby et al., 1995, 1998; Latouche et al., 1998). Then consumers are presented with a price to see if they are willing to pay that amount for a certain safety level and, after responding positively, they are then presented with a higher price for even more safety and so on. If the consumer responds 'no' the first time, the second price is some amount and safety level lower than the first price.

In a conjoint analysis, consumers are asked to rank a number of attributes related to the vegetable including attributes on food safety and price. Unlike contingent valuation, the conjoint method does not ask directly whether a consumer would be willing to pay for a vegetable with particular attributes (Halbrendt et al., 1995). A limitation of these direct valuation methods is incomplete information of the respondents or information bias, since if contamination is not visible to the naked eye, they are not able to observe the level of risk, or even if they are able to see it, the consequences of contamination such as severity and health costs are difficult to judge (for more details of this problem on information bias and other biases, see Birol et al., 2006).

Finally, WTP can be modelled as a function of the severity and duration of illness, reduction in probability and respondent characteristics (Hammitt and Haninger, 2007).

\section{Approach for assessing economic impacts on livelihoods}

Various approaches - qualitative or quantitative analysis or a combination of both - can be used to assess the impact of microbial pathogen exposure from using wastewater for irrigation on livelihood outcomes including farm income, wealth (savings/insurance), food and nutrition security, and gender equality. Here, the best known Sustainable Livelihood Framework (SLF) documented by the UK Department for International Development (DFID) is used to enable understanding of the impact of wastewater-based microbial pathogen exposure on livelihood assets, transforming structures and processes, and livelihood strategies (DFID, 2000). ${ }^{2}$ Impacts of pathogen exposure/contamination on all of these components will affect various livelihoods outcomes including farm income, wealth (savings/insurance), food and nutrition security, and gender equality. 
Household livelihood outcomes in turn determine the level of future vulnerability of the households to various shocks and stresses, including excretarelated diseases such as diarrhoea and helminth infections, and outbreaks of hepatitis $A$ and viral enteritis.

Qualitative methods such as focus group discussions and participatory rapid appraisal of the knowledge, attitudes and perceptions of health consequences of producing or consuming fruits and vegetables irrigated with wastewater would capture the dynamic changes in livelihood strategies. A participatory value-chain mapping can also be done to understand the basic relationships between valuechain actors and the structure of flows of products from raw material supply to the end consumer market, and to assess the value of losses due to microbial contamination (Hellin et al., 2005). This involves participatory observation, semistructured interviews and focus group discussions to map the flow of produce irrigated with wastewater from farm to final consumer, in order to identify the key actors along the chain and understand the role of wastewater irrigation in their livelihoods (income, health and nutrition). Mapping the value chain can also help identify high- and low-risk areas along the chain, market failures and coordination mechanisms, incentives that may impede or facilitate the uptake of the multiple-barrier approach to prevent contamination and reduce health risks at all stages of the chain. It can also identify regulatory and market issues that may hinder or enhance functions of institutions and organizations providing services such as input supplies, market information, credit and quality standards that the different actors need to help them decide whether to adopt or apply control and preventive measures.

Quantitative methods such as regression analysis, covariate and propensity score-matching, and difference-in-difference estimators and empirical models for estimating differential treatment effects can be used to analyse the impact on livelihoods. This will involve structured household and quantitative value-chain surveys that will enable understanding of the full economic impacts of pathogen reduction measures on the poor's livelihood asset portfolio ${ }^{3}$ and outcomes including income, health and nutrition. The quantity and quality of these assets and access to them are influenced by pathogen contamination, including trends (e.g. during the hungry season), shocks (e.g. diarrhoeal outbreak) and stresses (e.g. chronic diarrhoea). Households are viewed as being sustainable if they can cope with trends, shocks and seasonality without compromising their future ability to survive these.

Interventions to control or reduce risk of pathogen contamination/exposure can occur at various stages along the food chain, from production, during harvest and post-harvest. These may include wastewater treatment technologies and non-treatment options: water-quality improvements, human-exposure control, farm-level wastewater management, and harvest and post-harvest interventions (see Box 7.2 above and Qadir et al., 2008, for a detailed description of these riskreduction interventions). Wastewater treatment technologies can achieve 1-6 log 
units of pathogen reduction and a tolerable disease burden of $<10^{-6}$ DALYs per person per year but this treatment is very expensive to implement in developing countries (Carr, 2001; WHO, 2006). There are non-treatment measures such as drip irrigation and washing of produce that protect farmers and consumers at low cost and can effectively minimize crop and human exposure by up to $6 \log$ units of pathogen reduction (WHO, 2006).

Regression analysis could be used to examine impacts on livelihood outcomes with the measure of pathogen exposure as an explanatory variable controlling for various household-level factors that affect livelihood outcomes such as income from vegetable production and morbidity of adults and children. The measure of exposure can be grouped into high versus low exposure, and with and without disease or diarrhoeal outbreak.

\section{Methods for evaluating the long-term economic impacts of interventions}

The choice of method to evaluate the long term impact of cost-effective interventions on livelihoods and health is guided by the nature of the problem, the intervention chosen and its related goal and purpose, which in this case is reducing pathogen contamination/exposure resulting from wastewater irrigation. First, it is necessary to conduct a baseline survey to obtain good pre-intervention measures of both livelihood strategies and livelihood outcomes, because this will be crucial to obtaining good measures of intervention impacts when a package of cost-effective control measures is introduced. The baseline survey will collect information related to health, education, behaviours, preferences and water usage, and address questions on how illness/disease due to contact with untreated wastewater results in asset loss (either via price or via short-term loss of market to sell vegetable crops irrigated with wastewater). A baseline risk assessment is also needed to estimate exposures and prevalence of pathogen contamination. ${ }^{4}$

Surveys on knowledge, attitude, perception and practices (KAPP) towards wastewater use for irrigation and food preparation, as well as behavioural experiments (choice experiments or actual field experiments), could be employed to determine the farmers' and consumers' willingness to adopt cost-effective mitigation measures. Behavioural experiments are also useful in investigating what kind of institutions would be preferred by what type of households and how households' preferences for different institutional mechanisms (e.g. incentives, subsidies) are affected by their livelihood outcomes (e.g. income from vegetable production, total income, food and nutrition security, etc.).

Currently, assessment of the poor's knowledge and perceptions of the risk of foodborne diseases associated with crops irrigated with wastewater is limited (Faruqui et al., 2004). There is a need for a comprehensive evaluation of WTP for intervention technologies with consideration of the sustainability, cultural 
acceptability, economic feasibility, ethical acceptability and overall effectiveness of potential interventions. One step towards achieving this is to determine why there is inadequate understanding of the risk of foodborne disease associated with irrigating with wastewater and ways to mitigate that risk, followed by identifying effective ways to enhance understanding. A proven approach to doing this is valuechain analysis that focuses on the awareness, attitudes, perceptions, knowledge and practices of value-chain actors regarding wastewater use so as to understand how best to encourage farmers (and other actors along the value chain) to adopt riskreduction measures. Such an analysis provides insight into the rationale behind value-chain actors' lack of understanding of the potential health risks associated with wastewater use for irrigation.

A structured questionnaire as well as participatory assessment can be used to collect KAPP information for wastewater irrigation. Questions can be ranked and scored according to cost-effectiveness in preventing infection due to wastewater use. These scores are the weighted measure of KAPP related to reduction of risk of infection. For example, five points can be awarded to the most important mitigation measure and one point for the least important. The percentage score is the sum of scores divided by the sum of available points (proportional piling). Results from this KAPP could help in understanding why the poor's management of wastewater use is inadequate. If the stakeholders were made aware of the health and income-loss risks, and which strategies were cost-effective to adopt, they might be more willing to implement such strategies.

Given the health risks associated with wastewater use and the importance of targeting effective and appropriate mitigation strategies, it is important not only to understand what farmers or consumers say they will do or say they prefer, but to truly observe what they actually do or actually choose. Randomized controlled trials allow us to observe the greatest impact of interventions on assets and livelihood outcomes (incomes, health and nutritional status), in real conditions, of different strategies and approaches to induce behaviour-change (Dupas et al., ongoing). This would involve counterfactual analysis to generate distributions of livelihood outcomes without interventions (control group), and to compare these to the actual distributions (treatment group) (DiNardo et al., 1996). The intervention's impact can be calculated from simple mean difference between the outcomes of the control and the treatment groups: Impact = Mean (Outcome of Eligible Random Treatment group) - Mean (Outcome of Eligible Random Control group). Data can also be further analysed to understand the differential impact on different subgroups within the sample.

Random assignment also assures the direction of causality, i.e. offering watering cans or drip kits to farmers causes a reduced disease burden on lettuce leaves. In a case where the intervention is only offered to better-educated farmers from the outset it is possible that this group is likely to be different from less-educated farmers in a variety of ways, such as differing hygiene practices and other behaviours which impact on health; thus, the impact of the intervention on this group will not 
be representative of the impact on all farmers. Additionally, if the control group is not identical to the treatment group, such as better-educated farmers receiving the programme compared to less-educated farmers serving as the control, the evaluation will not accurately show the programme's effects. These farmers are likely to have different behaviours and perhaps different health realities independent of the intervention, so the programme's affect on one group will be very different from the potential programme affect on the other, and the two groups will be experiencing different external events. The benefit of assigning the treatment or programme randomly is that we know there are no significant differences between the treatment and control groups. In choosing the treatment group, selection bias may be encountered. This problem of selection bias can be removed from impact estimates by 'instrumenting' adoption, that is, by finding exogenous variables that explain adoption but do not affect the outcomes. However, it is difficult to find such exogenous instruments and so instrumental variables may only identify part of the treatment effect.

With baseline data collected before the intervention, there should be one or more follow-up evaluation surveys (comparable questionnaires or interviews to the baseline) on the same groups after the interventions are put in place. The data collected would allow for the double difference method to measure the long-term economic impact (lower medical costs and lower productivity losses) and health impact (lowest pathogen levels and more than 50 per cent reduction in foodborne illness). As the first difference, it compares treatment (participants/adopters of intervention) and control (non-participants/non-adopters of interventions) groups. Subsequently, before and after intervention outcomes are compared as the second difference. The impact of the intervention is the mean difference between the 'before' and 'after' values of the outcome for each of the treatment and control groups.

\section{ConClusions}

Increasing use of wastewater for irrigating vegetable crops will continue as long as wastewater treatment remains limited while populations and demand for food increase, especially in the developing world. As verified in the other chapters of this volume, wastewater irrigation poses a health problem for the entire food chain, thus requiring a multidisciplinary approach for analysis. This chapter provided a discussion of various methods to evaluate the economic impacts of a disease, the costs and benefits of interventions and the willingness to adopt or pay for interventions. Second, the chapter aimed to provide a methodological framework to enable the collection and analysis of data to measure the economic impacts of illness/disease caused by microbial pathogens from wastewater on household assets; livelihood strategies to reduce the risk of illness/ waterborne disease; diversification patterns such as investment in non-treatment interventions or shifting to other 
livelihoods activities; and the various indicators of producer livelihoods, including income, nutrition and food security, and gender equality. The proposed framework addresses some of the challenges in evaluating cost-effective interventions and strategies for the poor to adopt so as to reduce the risk of illness/disease associated with wastewater use.

The lack of awareness and knowledge of poor producers and consumers of the potential impact of wastewater use for irrigation on health, as well as lack of information on appropriate food hygiene and sanitary practices, can all be addressed through KAPP analysis. In prioritizing interventions to improve health and livelihood outcomes, poor people's knowledge and perception of risk, as well as their willingness to pay for or adopt cost-effective ways to reduce health risks associated with wastewater use, must be taken into consideration. Promoting behaviour-change requires a longer period of time, incentives and frequent reinforcement, especially to those most vulnerable or at risk.

Randomized controlled trials can and should be used both to measure impact and to conduct product-innovation testing. Testing product or programme innovations, however, involves offering a programmatic innovation to a randomly selected pool of farmers, consumers, business owners, etc., while the control group has only access to the standard programme or services. Randomized controlled trials can be beneficial in developing and improving programmes and measuring the impact on usage, disease burden, operational efficiency and marketing.

To conclude, it would be ideal to use a combination of a before and after approach, and a with and without intervention approach, to capture the changes in the difference. The problem with this counterfactual analysis is finding a group 'without intervention' not too close to the 'with intervention' group, so as to avoid spillover effects or contamination. It is also possible that the 'without intervention' group, when the baseline data are collected, will have some intervention introduced between the time of the baseline and endline surveys. A mid-term survey is therefore suggested to allow an initial check on impact and to allow analysis of changes in impact over time. Data collection should be designed to include baseline, followup and endline surveys for the evaluation of interventions to reduce the risk of infection/contamination associated with wastewater use over the long term. In the final instance, interventions that are implemented should be proven to protect the livelihoods of the poor producers, traders and consumers so that adoption of these interventions will become sustainable in the long run.

\section{Notes}

1 We take livelihoods as the set of activities, e.g. crop farming, livestock rearing and off-farm employment, on which (poor) households base their welfare or well-being (Chambers and Conway, 1992). A household's livelihood is sustainable when it can cope with and recover from external shocks (such as civil conflict or emergence of 
new human, crop or livestock diseases) and stresses (e.g. recurrent adverse weather and seasonality), and can maintain or enhance its capabilities and assets, while not undermining the natural resource base (Chambers and Conway, 1992; Ellis, 2000; Scoones, 1998).

2 The three components of the framework are: (a) livelihood assets: changes in a household's asset portfolio including, for example, changes in irrigation facilities; changes in human capital in the form of information and education, as well as better health and nutrition; changes in infrastructure (e.g. good agricultural practices, hygienic handling practices, better storage facilities) to improve income, food security and health; (b) transforming structures and processes: changes in institutions, such as minimum standards for microbial pathogen reduction, implementation of hazard analysis and critical control points (HACCP) regulations at different stages of the value chain, capacity strengthening of laboratories and changes in markets (e.g. demand, prices, etc.). Attention will be given to the role of markets and institutions supporting markets access and reduced transaction costs to identify livelihood opportunities and constraints; (c) livelihood strategies: ex post strategies such as consuming rather than selling contaminated vegetables; ex ante mitigation strategies, such as adopting pathogen reduction measures in both production and consumption by, for instance, investing in drip or spray irrigation, washing and disinfecting of produce, etc.

3 Household assets consist of the stock of resources used to generate well-being (Jansen et al., 2005). Assets include human capital (e.g. number of household members, their gender and age, skills, knowledge (indigenous/local or formal through extension training), informal and formal education, good health, ability to work, household size and demographics); natural capital (e.g. climate, land (inherited or acquired), soil, water (treated or untreated), stream, borehole, soil (quality and fertility)); physical capital (numbers and types of livestock, production equipment and technologies, transportation); financial assets (cash, transfers, credit/debit, savings); locationspecific factors such as access to infrastructure and public services; and social capital (social networks, social relations, membership in national or village-level producer associations, etc.).

4 When conducting the risk assessment, the exposure assessment will estimate the baseline prevalence of waterborne illness (e.g. acute gastroenteritis, diarrhoea, hepatitis A, amoebiasis, dysentery, etc.) associated with exposure to microbial pathogens (such as rotavirus, norovirus, Legionella spp., Salmonella spp., E. coli, Giardia intestinalis, helminths, and many more) in wastewater on a society.

\section{REFERENCES}

Asano, T., Leong, L. Y. C., Rigby, M. G. and Sakaji, R. H. (1992) 'Evaluation of the California wastewater reclamation criteria using enteric virus monitoring data', Water Science and Technology, vol 26, nos 7-8, pp1513-24

Bennett, R., Cooke, R. J. and Ijpelaar, J. (2004) 'Assessment economic impacts of TB and alternative control policies', SE3112, Final Project Report to the Department for Environment, Food and Rural Affairs, London 
Birol, E., Karaousakis, K. and Koundouri, P. (2006) 'Using economic valuation techniques to inform water resources management: A survey and critical appraisal of available techniques and an application', Science of the Total Environment, vol 365, pp105-22

Blumenthal, U. J., Peasey, A., Ruiz-Palacios, G. and Mara, D. D. (2000) Guidelines for Wastewater Reuse in Agriculture and Aquaculture: Recommended Revisions Based on New Research Evidence, Task No 68, Part 1, WELL Study, London School of Hygiene and Tropical Medicine, London / Loughborough University, Loughborough

Buechler, S. and Devi, G. (2005a) 'Local responses to water resource degradation in India: Groundwater farmer innovations and the reversal of knowledge flows', Journal of Environment and Development, vol 14, no 4, pp410-38

Buechler, S. and Devi, G. (2005b) 'Household food security and wastewater-dependent livelihood activities along the Musi River in Andhra Pradesh, India', WHO, Geneva, www.who.int/water_sanitation_health/wastewater/gwwufoodsecurity.pdf

Buzby, J. C., Fox, J. A., Ready, R. C. and Crutchfield, S. R. (1998) 'Measuring consumer benefits of food safety risk reductions', Journal of Agricultural and Applied Economics, vol 30, pp69-82

Buzby, J. C., Ready, R. C. and Skees, J. R. (1995) 'Contingent valuation in food policy analysis: A case study of a pesticide-residue risk reduction', Journal of Agricultural and Applied Economics, vol 27, pp613-25

Carr, R. (2001) 'Excreta-related infections and the role of sanitation in the control of transmission', in L. Fewtrell and J. Bartram (eds) Water Quality: Guidelines, Standards and Health; Assessment of Risk and Risk Management for Water-Related Infectious Disease, International Water Association (IWA) on behalf on the World Health Organization, London, pp89-113

Chambers, R. and Conway, G. (1992) 'Sustainable rural livelihoods: Practical concepts for the twenty-first century', IDS Discussion Paper No. 296, Institute of Development Studies, Brighton, UK

Department of International Development (DFID) (2000) Sustainable Livelihoods Guidance Sheets, DFID, London, www.dfid.gov.uk

DiNardo, J., Fortin, N. M. and Lemieux, T. (1996) 'Labor market institutions and the distribution of wages, 1973-1992: A semiparametric approach', Econometrica, vol 64, pp1001-44

Disney, R., Emmerson, C. and Wakefield, M. (2003) 'Ill-health and retirement in Britain: A panel data-based analysis', Working Paper No. 03-02, Institute of Fiscal Studies, London

Dupas, P., Kremer, M. and Zwane, A. (ongoing) 'The demand for safe water among mothers of young children in Kenya', Innovations for Poverty Action, New Haven, CT, http://poverty-action.org/work/projects/0081

Ellis, F. (2000) Rural Livelihoods and Diversity in Developing Countries, Oxford University Press, Oxford

Ensink, J. H. J. (2006) 'Water quality and the risk of hookworm infection in Pakistani and Indian sewage farmers,' $\mathrm{PhD}$ thesis, London School of Hygiene and Tropical Medicine, University of London, London

Ensink, J. H. J., Mahmood, T., van der Hoek, W., Raschid-Sally, L. and Amerasinghe, F. P. (2004) 'A nationwide assessment of wastewater use in Pakistan: An obscure activity or a vitally important one?', Water Policy, vol 6, pp197-206 
Ensink, J. H. J., van der Hoek, W., Matsuno, Y., Munir, S. and Aslam, M. R. (2003) 'The use of untreated wastewater in peri-urban agriculture in Pakistan: Risks and opportunities', IWMI Research Report 64, International Water Management Institute, Colombo

Faruqui, N. I., Scott, C. A. and Raschid-Sally, L. (2004) 'Confronting the realities of wastewater use in irrigated agriculture: Lessons learned and recommendations', in C. A. Scott, N. I. Faruqui and L. Raschid-Sally (eds) Wastewater Use in Irrigated Agriculture: Confronting the Livelihood and Environmental Realities, CABI Publishing, Wallingford, UK, pp173-85

Fattal, B., Lampert, Y. and Shuval, H. (2004) 'A fresh look at microbial guidelines for wastewater irrigation in agriculture: A risk assessment and cost-effectiveness approach', in C. A. Scott, N. I. Faruqui and L. Raschid-Sally (eds) Wastewater Use in Irrigated Agriculture: Confronting the Livelihood and Environmental Realities, CABI Publishing, Wallingford, UK, pp1-10

Fearne, A., Garcia, M., Bourlakis, M., Brennan, M., Caswell, J., Hooker, N. and Henson, S. (2004) 'Review of the economics of food safety and food standards', report prepared for Food Standards Agency, Imperial College, London

Feenstra, S., Hussain, R. and van der Hoek, W. (2000) 'Health risks of irrigation with untreated urban wastewater in the southern Punjab, Pakistan', IWMI Pakistan Report, no 107, International Water Management Institute, Lahore

Ginneken, M. van and Oron, G. (2000) 'Risk assessment of consuming agricultural products irrigated with reclaimed wastewater: An exposure model', Water Resources Research, vol 36, pp2691-9

Glauber, J. and Narrod, C. (2001) A Rational Risk Policy for Regulating Plant Diseases and Pests, AEI-Brookings Joint Center for Regulatory Studies, Washington, DC

Halbrendt, C., Pesek, J., Parsons, A. and Linder, R. (1995) 'Using conjoint analysis to assess consumers' acceptance of pST-supplemented pork', in J. A. Caswell (ed) Valuing Food Safety and Nutrition, Westview Press, Boulder, CO, pp129-53

Hamilton, A. J., Boland, A. M., Stevens, D., Kelly, J., Radcliffe, J., Ziehrl, A., Dillon, P. J. and Paulin, R. (2005) 'Position of the Australian horticultural industry with respect to the use of reclaimed water', Agricultural Water Management, vol 71, pp181-209

Hamilton, A. J., Stagnitti, F., Boland, A. M., Premier, R. and Hale, G. (2006) 'Quantitative microbial risk assessment models for consumption of raw vegetables irrigated with reclaimed water', Applied and Environmental Microbiology, vol 72, pp3284-90

Hammitt, J. K. (2000) 'Evaluating contingent valuation of environmental health risks: The proportionality test', Association of Environmental and Resource Economists Newsletter, vol 20, no 1, pp14-19

Hammitt, J. K. and Haninger, K. (2007) 'Willingness to pay for food safety: Sensitivity to duration and severity of illness', American Journal of Agricultural Economics, vol 89, no 5, pp1170-75

Havelaar, A. H., Bräunig, J., Christiansen, K., Cornu, M., Hald, T., Mangen, M.-J. J., Mølbak, K., Pielaat, A., Snary, E., Van Boven, M., Van Pelt, W., Velthuis, A. and Wahlström, H. (2006) Towards an Integrated Approach in Supporting Microbiological Food Safety Decisions, Report no 06-001 for the project on Network for the Prevention and Control of Zoonoses (project FOOD-CT-2004-506122) funded by the European Commission and co-supported by the Dutch Food and Consumer Safety Product Authority, Med-Vet-Net and RIVM, The Netherlands 
Hellin, J., Griffith, A. and Albu, M. (2005) 'Mapping the Market: market-literacy for agricultural research and policy to tackle rural poverty in Africa', in F. R. Almond and S. D. Hainsworth (eds) Beyond Agriculture - Making Markets Work for the Poor. Proceedings of an International Seminar, February 28-March 1, 2005, Natural Resources International Limited and Practical Action, London

Hoek, W. van der, Ul Hassan, M., Ensink, J., Feenstra, S., Raschid-Sally, L., Munir, S., Aslam, R., Ali, N., Hussain, R. and Matsuno, Y. (2002) 'Urban wastewater: A valuable resource for agriculture - A case study from Haroonabad, Pakistan', IWMI Research Report no 63, International Water Management Institute, Colombo, p20

Hope, L. and Keraita, B. (2009) unpublished project data, IWMI Ghana, Accra

IWMI (2006) 'Recycling realities: Managing health risks to make wastewater an asset', Water Policy Briefing no 17, International Water Management Institute in partnership with the Global Water Partnership (GWP) Advisory Center at IWMI and the GWP Technical Committee, Colombo

Jansen, H. G. P., Siegel, P. B., Alwang, J. and Pichon, F. (2005) 'Geography, livelihoods and rural poverty in Honduras: An empirical analysis using an asset-based approach', Working Paper No 134, Ibero-America Institute for Economic Research (IAI), Göttingen

Jiménez, B. and Asano T. (2004) 'Acknowledge all approaches: The global outlook on reuse', Water, no 21, December 2004, pp32-7

Keraita, B. (2008) 'Low-cost measures for reducing health risks in wastewater-irrigated urban vegetable farming in Ghana', PhD dissertation, Faculty of Health Sciences, University of Copenhagen, Copenhagen

Latouche, K., Rainelli P. and Vermersch, D. (1998) 'Food safety issues and the BSE scare: Some lessons from the French case', Food Policy, no 23, pp347-56

Malcolm, S., Narrod, C., Roberts, T. and Ollinger, M. (2004) 'Evaluating the economic effectiveness of pathogen reduction technologies in cattle slaughter plants', Agribusiness: An International Journal, vol 20, no 1, pp109-24

Petterson, S. R., Ashbolt, N. and Sharma, A. (2001) 'Microbial risks from wastewater irrigation of salad crops: A screening-level risk assessment', Water Environment Research, vol 72, pp667-72

Qadir, M., Wichelns, D., Raschid-Sally, L., McCornick, P. G., Drechsel, P., Bhari, A. and Minhas, P. S. (2008) 'The challenges of wastewater irrigation in developing countries', Agricultural Water Management, in press, doi 10.1016/j.agwat.2008.11.004

Scoones, I. (1998) 'Sustainable rural livelihoods: A framework for analysis', IDS Working Paper no 72, University of Sussex, Institute of Development Studies, Brighton, UK

Scott, C. A., Faruqui, N. I. and Raschid-Sally, L. (2004) 'Wastewater use in irrigated agriculture: Management challenges in developing countries', in C. A. Scott, N. I. Faruqui and L. Raschid-Sally (eds) Wastewater Use in Irrigated Agriculture: Confronting the Livelihood and Environmental Realities, CABI Publishing, Wallingford, UK, pp110

Shuval, H. I., Adin, A., Fattal, B., Rawitz, E. and Yekutiel, P. (1986) Wastewater Irrigation in Developing Countries - Health Effects and Technical Solutions, World Bank Technical Paper no 51, UNDP Project Management Report, Washington, DC

Shuval, H. I., Lampert, Y. and Fattal, B. (1997) 'Development of a risk assessment approach for evaluating wastewater reuse standards for agriculture', Water Science and Technology, no 35, pp15-20 
Smith, G. C., Bennett, R., Wilkinson, D. and Cooke, R. (2007) 'A cost-benefit analysis of culling badgers to control bovine tuberculosis', Veterinary Journal, vol 173, no 2, pp302-10

Tanaka, H., Asano, T., Schroeder, E. D. and Tchobanoglous, G. (1998) 'Estimating the safety of wastewater reclamation and reuse using enteric virus monitoring data', Water Environment Research, vol 70, no 1, pp39-51

Toze, S. (2006) 'Reuse of effluent water-benefits and risks', Agricultural Water Management, no 80 , pp147-59

Valeeva, N. I., Meuwissen, M. P. M. and Huirne, R. B. M. (2004) 'Economics of food safety in chains: A review of general principles', NJAS Wageningen Journal of Life Sciences, vol 51, no 4, pp369-90

WHO (2006) Guidelines for the Safe Use of Wastewater, Excreta and Greywater, Volume 2: Wastewater Use in Agriculture, World Health Organization, Geneva 